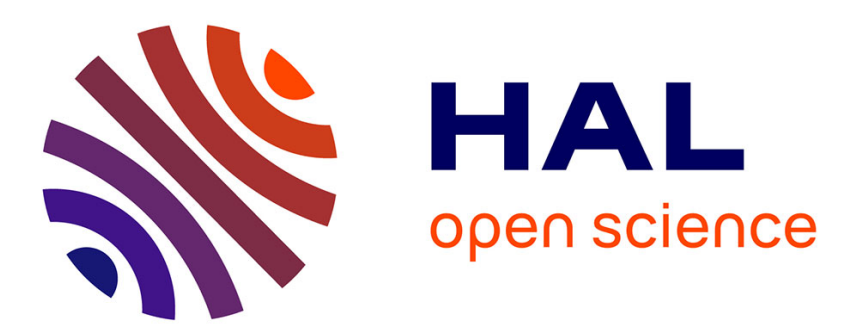

\title{
Writing and Achievement at University as Individualistic or Social Practices: Two Latino Undergraduates' Contrasting Approaches to Academic Success
}

\author{
Miki Mori
}

\section{- To cite this version: \\ Miki Mori. Writing and Achievement at University as Individualistic or Social Practices: Two Latino Undergraduates' Contrasting Approaches to Academic Success. Journal of Language, Identity and Education, 2018, 18 (2), pp.126-140. 10.1080/15348458.2018.1528546 . hal-02910318}

\section{HAL Id: hal-02910318 https://hal.science/hal-02910318}

Submitted on 1 Aug 2020

HAL is a multi-disciplinary open access archive for the deposit and dissemination of scientific research documents, whether they are published or not. The documents may come from teaching and research institutions in France or abroad, or from public or private research centers.
L'archive ouverte pluridisciplinaire HAL, est destinée au dépôt et à la diffusion de documents scientifiques de niveau recherche, publiés ou non, émanant des établissements d'enseignement et de recherche français ou étrangers, des laboratoires publics ou privés. 
Mori, Miki. (2019). Writing and achievement at university as individualistic or social practices: Two Latino undergraduates' contrasting approaches to academic success. Journal of Language, Identity \& Education, 18(2), 126-140. https://doi.org/10.1080/15348458.2018.1528546

Writing and achievement at university as individualistic or social practices: Two Latino undergraduates' contrasting approaches to academic success.

\section{Miki Mori}

\section{Associate Professor of Linguistics}

\section{CUFR Mayotte}

mikimorimayotte@gmail.com

\section{Introduction}

"Because they're like 'the system puts you down' but it's more like 'your self puts you down."”
-Martin
"It is important that minority students step up and ask for help."
-Raquel

The above quotes come from conversations I had with two undergraduate students on the topic of Latinos and education. I met Raquel and Martin while they were in their last year at a large public West Coast university in the U.S. and taking a writing class for future educators. Both had struggled throughout their primary and secondary school years, only to find themselves again challenged in college. Until middle school, Martin lived with his father and three siblings in a one-room house, and because his dad worked at a landfill in the early morning, he required the lights to be turned off at $8 \mathrm{pm}$, making it impossible for Martin to do his homework. He performed poorly at school and developed an attitude of "I don't like school" (Interview, 11/20/12).Though he expressed a dislike for school, Martin enrolled in a community college after high school because his father gave him two options: pay rent or continue school. Once there, Martin befriended students planning to transfer to university and he met professors who inspired him, so after three years Martin decided to transfer. Raquel 
applied to university at the insistence of a school mentor. However, after enrolling at the university, she realized the aspirations and capabilities of the students at her high school were low and that she was not given fair preparation for college (Interview, 4/24/13). The paths by which they continued through university diverged, mainly in terms of social support and capital.

Though they came from similar backgrounds as working class, first generation Mexican Americans, Martin and Raquel held opposing views on how to succeed in school. In Martin's quote, the "they" are Latinos, whom he believes victimize themselves and blame others rather than taking personal responsibility. Though Raquel also asks for personal responsibility when she asks students to "step up," she wants them to get the courage to seek out social support in order to achieve. Their opinions mirrored their personal experiences. Whereas Martin described his educational success as stemming from his own hard work and will power, Raquel discussed the social network of professors, teachers, and mentors that helped her succeed. The two had opposing views on the cause of their college success, and these attitudes affected their interaction on campus. Whereas Raquel actively sought social support, Martin deliberately avoided seeking help, explaining once it was because "men are scared" (Interview, 11/20/12). However, these two opinions were not diverging-yet-harmless approaches to academic success, nor were their trajectories as undergraduates smooth. Once at the university, Martin and Raquel struggled to maintain a minimum GPA (Grade Point Average) and were placed on academic probation. Raquel was dismissed the end of her freshman year but attended a community college for a year, where she was able to raise her GPA and return to the university. Raquel went on to graduate from the university, whereas Martin was permanently dismissed during his last year due to his low GPA.

I encountered the two students while researching the writing processes of upper division university students. While working with Raquel and Martin on their writing, I 
wondered what connections there might be between their school success strategies and their writing habits, such as the way they interacted with their peers or approached research articles. This study explores how two students' writing practices paralleled their techniques for educational success. It also demonstrates the ways in which identity and agency play a part in writing.

The goals of this article are twofold. First, I highlight the educational histories as told by two individuals from a demographic that is often cited in educational statistics as at risk and underrepresented. Their stories can inform educators on how students understand the elements in their life histories that have helped them succeed. As undergraduates in their final year, these are the students who not only made it to college (Kanno \& Harklau, 2012) but arguably through college. The second goal focuses on showing the influence an individual's history and approach to schooling can have on research-based writing practices at the university.

\section{Discussion of relevant literature: Success stories, constraint agency, and symbolic capital}

This study finds itself in dialogue with various threads of research on language and education, specifically research on student background, writing, identity and agency. Analyzing student experiences can be addressed in a variety of ways, such as how they offer insight into individuals' understanding of their life circumstances and their subsequent life choices (Harklau \& McClanahan, 2012; Reyes, 2009; Varghese, 2012). When people tell stories about their past, they evaluate events and offer an explanation of how they arrived at their current state. For example, Harklau and McClanahan (2012) used a student's retelling of her past to understand how one student, Paola, graduated from high school and entered university despite the odds. They discovered that esteem building activities such as sports contributed to Paola's success, as well as self-determination. For this study, it is a question of how individuals tell their story of navigating through primary, secondary and post-secondary 
schooling. I call these "success stories" because they explain how individuals achieved their educational status.

In addition, for underrepresented individuals facing challenges and lacking in capital, analyzing their histories with the framework of "constraint agency" (Varghese, 2012) reveal ways in which individuals demonstrate agency under particular limitations. Constraint agency draws upon Bourdieu's $(1977,1986)$ theory of agency and capital, but adds to the theory by highlighting the constraints particular individuals have in an educational system (Mills and Gale, 2007). In a general sense, agency is a person's ability to enact, change, and do. Ahearn (2001) succinctly describes it as "the socioculturally mediated capacity to act" (p. 112). In school settings, agency relates often relates to Bourdieu's (1977) concepts of structured systems and real and symbolic capital. In essence, there are intact structural constraints of academia (power hierarchies, privileged knowledge, grades, and fees).

In this system, individuals are more apt to succeed in such structures when they have real capital, enabling them to pay for tuition fees. In fact, low SES (Socioeconomic Status) has been correlated with lower achievement rates in higher education (Walpole, 2003). Besides monetary capital there is symbolic capital, which does not directly involve finances. Possessing different types of symbolic capital helps remove educational constraints that people may have due to lack of real capital. Rather, it pertains to particular skillsets that are valued in a society, termed cultural capital, ranging from the home literacy practices (Heath, 1982) to the type of high school attended. Furthermore, cultural capital can include academic and linguistic elements. Knowledge pertaining to the educational system, such as interacting with professors, attending office hours, and receiving feedback on writing is a form of academic capital. Linguistic capital in school involves knowledge of academic language or the jargon of a specific discipline (see Brammer, 2002). Importantly social capital addresses the social networks people have that allow them access to privileged information such as 
mentors, educated family members, and peers from privileged groups. Often students lack a mixture of real and various types of symbolic capital, such as the students in Kanno and Varghese's (2010) study on ESL community college students, who lacked real and linguistic capital.

It is logical to assume that those lacking in real and symbolic capital experience limitations in what they are able to do. Nevertheless, people exercise agency in a variety of ways in education, such as through what they decide to do in class, how they interact with classmates, whether or not they apply to college, etc. For example, Varghese (2012) researched a student's constraint agency in discussing how she was able to make it through her first years of undergraduate study. Varghese found that the student was able to practice agency by resisting some habits of the academy but embracing others. Similarly, though they did not frame the factors that contributed to her success, Harklau and Kanno's (2012) analysis revealed that various kinds of social and cultural capital helped the individual enter college. For this study's focal participants, Martin and Raquel often lacked the economic, cultural, and social capital needed during k-12 to prepare them for university. This includes being low income (lack of real economic capital), not completing AP or Honors classes (academic capital), receiving cultural messages that emphasized work and family commitments (cultural capital), and not having family members who attended college (social capital). They represent a population of students that face serious challenges in higher education, often not obtaining the same level of academic success as their monolingual, Anglo peers (Kanno et al., 2013).

\section{The intersection of identity and writing}

Understanding one's past in school involves identity work. Hall (1996) describes identity as something that is in creation rather than created and it is a composite of internal and external perceptions of the self: 
Identities are about questions of using the resources of history, language, and culture in the process of becoming rather than being: not 'who we are' or 'where we came from,' so much as what we become, how we have been represented and how that bears on how we represent ourselves. (p. 4, italics added)

Rather than discounting one's past, Hall argues that people's identities are forged over the course of history as opposed to existing in a singular, stable way. These embodied histories include past experiences, social interactions, and imposed ideologies. New situations influence how identities are enacted. As Holland, Lachicotte Jr., Skinner, and Cain (1998) note, identities are "possibilities for mediating agency" (p. 4). There is an agentive force that shapes identity, which is neither fixed by history nor spontaneously created in a given moment (Holland et al., 1998). Multiple identities can be created, are never permanent, and always a struggle (Norton, 1997). Identity can consist of how people see themselves in terms of their histories with schooling and family background, including culture and language (Harklau, McClanahan, \& Mendez, 2012; Ivanic, 1998; Ivanic \& Camps, 2001; OrtmeierHooper, 2008).

Identity work occurs through writing of a personal element, such as narratives, expressivist genres, and even research papers. Identity becomes a formative, social process that can be witnessed during the writing process and whose vestiges can be seen in drafts (Ivanic, 1998). The adult student writers in Ivanic's (1998) study demonstrated struggles with identity in the academy, such as whether or not to use quotations because their use might suggest valuing outside authority over personal experience (p. 231). Some have urged undergraduate writing should emphasize the student as a person with legitimate experience because writing is more meaningful when students can synthesize their lives with the academy. Comfort (2000) argues writing should enable students to "recognize the writerly self as a persuasive instrument that can be strategically deployed...to take personal stands on 
public issues that transcend the confessional" (p 555, original italics). Identity and writing are closely connected, as students bring their lived experiences into the writing classroom, creating a place for identity (re)creation and agency through writing. Given this potential, it is worthwhile to look more closely at writing and student experiences.

\section{Research Questions}

Understanding strategies for educational success and writing practices are worthwhile inquiries on their own. But I wanted to understand what sort of crossover there might be between the two: Might there be a connection between the schemas people profess to use to survive in education and how they maneuver through a writing course? Furthermore, although research has provided insight into first year writing courses in remedial, ESL and mainstream contexts (Collins, 1999; Lee, 2010; Liu \& Tannacito, 2013; Ortmeier-Hooper, 2008; Ramanathan \& Atkinson, 1999; Welch, 1996), we are yet to fully understand how students perform during the last years at university. Whereas Ivanic (1998) demonstrated the role of identity for mature writing students at university on their writing itself, we are left wondering what the role of identity and past histories might play on the writing process itself.

Considering the literature in this way brought me to ask the following interrelated research questions considering the two focal students.

1. How do Martin and Raquel describe their educational success via constraint agency?

2. How do Martin's and Raquel's approaches to educational success influence their writing process?

\section{Methods}

\section{Participants and setting}

This study developed from a larger project on the writing development of multilingual upper division undergraduate students at a large public university on the U.S. West Coast. I 
chose to look at Martin and Raquel because initial analysis revealed strong connections between their past experiences and their writing assignment where they were to research a problem in the educational system that interested them. As discussed in the introduction, Martin and Raquel had different perspectives on the role of their culture in their academic life and differing views on the writing course.

Moreover, as Latinos and Mexican Americans, Martin and Raquel represent a group of individuals historically underrepresented in post-secondary education despite their large numbers in k-12 education in states such as California and Texas (Santiago \& Calderon Galdeano, 2014). Recent studies show that Hispanic student enrollment in higher education as rising in states such as California (Freeling, 2015), but their graduation rates remain below the national average at $41 \%$ vs. $50 \%$ (Santiago \& Calderon Galdeano, 2014). Thus although progress appears to be made, an achievement gap remains for Hispanics becoming degreebearing individuals, with $20 \%$ vs. $36 \%$ of adults (Santiago \& Calderon Galdeano, 2014). Given these statistics, it is worthwhile to take a closer look at Martin's and Raquel's stories.

Table 1 shows demographic information. Regarding language background, Raquel was never tracked as an English Language (EL) learner and spent the first few years of k-12 in a Spanish-medium classroom before transitioning into English-medium classes with bilingual teachers; however, Raquel felt this experience put her at a disadvantage in school. Martin was tracked as an English Learner from elementary school through high school, even though he discussed not perceiving himself as one (Interview, 12/7/12). He failed the 5th grade and reported spending most of his middle and high school years not paying attention and sleeping in class.

\section{Table 1}

Martin Raquel




\begin{tabular}{|c|c|c|}
\hline Sex & Male & Female \\
\hline Ethnicity & Mexican & Mexican \\
\hline Age & 23 & $\mathrm{n} / \mathrm{a}^{*}$ \\
\hline Birthplace & U.S. & U.S. \\
\hline \multicolumn{3}{|l|}{ Education } \\
\hline Major & Chemistry & Sociology \\
\hline EL/ESL designation & Yes, in primary school & No \\
\hline Transfer student & Yes & No \\
\hline $1^{\text {st }}$ in family to attend college & Yes & Yes \\
\hline Want to attend graduate school** & Yes & Yes \\
\hline Want to teach & Yes & Unsure \\
\hline \multicolumn{3}{|l|}{ Language } \\
\hline Spoken with parents & Spanish & Spanish \\
\hline Studied in school & Spanish & Spanish \\
\hline
\end{tabular}

Research project and writing process

Martin and Raquel enrolled in an upper-division writing course designed for future educators, where they learned about education and writing policies in k-12 education. The focus of the course was twofold: to improve writing abilities and to learn about the field of education and its current issues. They had different instructors, both of whom were experienced, PhD-holding lecturers who had taught the course numerous times. Their syllabi included readings on education and writing tasks such as creating a lesson plan, a personal statement to apply to graduate school, and a multi-draft research paper about an issue in education, the focus of this article's analysis. For this paper, students were asked to identify a problem in the field of education that was personally relevant to them, research the problem, and present it in an essay. Martin and Raquel went through a process of selecting a topic, 
looking for literature, researching, drafting and receiving peer review; they focused on issues that had negatively affected their performance in school, specifically the importance of mentorship and student tracking, respectively. They discussed their struggles and the need for the educational system to address the lack of available capital for Latino students.

Students at the university are required to take one upper-division writing course before graduating. They can take a general writing course or a class designed for specific disciplines or careers, such as for engineering majors, health studies, future educators, etc. Only students fitting the course profile were supposed to enroll, but some had trouble with class availability and took whatever one fit their schedule. As for Martin and Raquel, they wanted to obtain a PhD. Raquel was interested in psychological research and was not sure if she wanted to teach. Martin expressed a desire to be a science teacher but did not talk about going to graduate school for teaching. Rather, he wanted to continue studying in the hard sciences like Chemistry. Nevertheless, they both seemed interested in the writing class activities.

\section{Methods and data analysis}

My research methodology grounds itself in classroom ethnographic (Watson-Gegeo, 1992) and case study methods (Duff, 2008). I focus on understanding phenomena holistically and look for meaningful patterns among various types of data, such as observations, interviews, and artifacts such as writing reflections, emails, and written drafts. Because I wanted to understand how individuals develop their academic writing skills and interact with texts and their past, I needed to spend time with them and read their writing. I passed eight hours interviewing Martin and two hours with Raquel, and I observed more than 10 hours of classroom time with Martin and three hours with Raquel. This unevenness in data collection is a result of constraints and happenstance. Raquel and Martin were a part of a larger classroom ethnography involving eight student participants and three classroom instructors. At the start of observations, the instructors introduced me, my research, and the possibility of working 
with me as a tutor during the class. Students were aware that I was a doctoral student who had taught writing for many years and was specializing in writing research. I offered my services as an incentive for their voluntary participation. The goal was to meet once per week during the 10-week quarter, but we met according to the student's availability; on average I spent five hours with each participant. I dedicated one meeting to interviewing students about their educational history. The rest of the time was spent discussing their drafts. Interviews took place on campus, either in my office or the public dining area. Interviews were audio recorded using a professional grade, hand-held digital recorder, and transcribed by me using loose transcription methods. Sections of interviews used for publication were re-transcribed for accuracy, such as (...) for pauses, false starts, etc. After each interview, I wrote fieldnotes. At the end of the quarter, I ended up with seven students instead of my goal of 10, so I decided to spend another quarter collecting data in the hopes of meeting more student participants. One of the instructors, Paula, welcomed me into the same class the following quarter, where I spent three additional observation hours and met Raquel, who was enthusiastic to work with me (thus I spent over 10 hours in Paula's class). I took extensive field notes and audiorecorded all classroom observations.

Despite these differences, I find their stories to be very important and comparable for research purposes. Although I met with Raquel twice, our time spent was illuminating and full of content. We had scheduled more sessions, but Raquel cancelled due to scheduling conflicts. Martin and I often talked about his life history and I had the impression he was looking for someone to talk to about his past. Because the research paper was about tracking and he felt he was tracked, we used his ideas in his papers as a starting point. I would ask him questions about his drafts and he would answer me, but he rarely came to me with specific questions about his writing. We also communicated through email after our sessions ended. I collected all drafts and written documents from each participant, which totaled 30 documents. 
Raquel's instructor had them write written reflection assignments, where she discussed topics such as her peers' feedback and her writing process. Martin's instructor had him write reflections at the end of his writing assignments.

My qualitative methods for analysis involved coding, recoding and tertiary coding (Strauss, 1987), as well as iterative reflection on findings and theories throughout the data collection process. Specifically, interviews, communications through emails, student writings and student written reflections were coded for references to types of symbolic and real capital, agency, individualism, and successes. As I began to observe during coding, I refined my codes and drew connections among them while simultaneously forming hypotheses for why certain patterns were emerging. I shared some of my initial findings with colleagues for feedback.

\section{Researcher positionality}

Because ethnographic case studies involve the researcher as an instrument, I provide information on my background. I am formally trained in linguistics, specializing in second language acquisition. In my doctoral studies, I specialized in writing studies and for four years taught first-year undergraduate writing to non-native speakers of English. I attended a large public university for my undergraduate studies. However, I was raised in a monolingual English household: My father is ethnically Japanese and my mother Western European; I have passed as someone who comes from a variety of regions, such as Chilean while in Chile and Thai while in Thailand. I was raised in a small farming town with a large number of migrant farm workers from Mexico, similar to Martin's hometown, and many of my friends growing up were Mexican. (Raquel was raised in large San Francisco Bay Area city.) These factors influence how I understood Martin's and Raquel's experiences. For example, I understood the 
cultural reference Martin made when he discussed being called a "cholo" ${ }^{1}$ by his White classmates, marking him as an outsider in the honors classes. This is because I had some “chol@" (male and female "cholos") friends growing up and was familiar with the culture and racial tensions of small migrant farming towns in California.

\section{Results: Diverging paths to college, different approaches to writing}

In the following sections, I discuss Raquel's and Martin's success stories and approaches to the writing process. Figure 1 is a flow chart showing their backgrounds and approaches to educational achievement and the research-writing process. Martin's individualistic success strategy for school achievement was also seen in how he approached outside sources, research, and feedback in writing. Likewise, Raquel's use of social structures to achieve in school was reflected in the way she drafted papers and researched her topic.

\footnotetext{
1 "Cholo" in a Californian context is a slang term that refers to a Latino who dresses and speaks in a manner associated with gang activity regardless if they are actually in a gang or not. It can be derogatory.
} 


\section{Demographic and background Experiences}

First generation Mexican Americans, first generation college students, lacked support in k-12 education

\section{Constraint Agency and Academic Success}

MARTIN: Success due to individual efforts, innate intelligence and "bootstraping;" distanced himself from Latino community
RAQUEL: Success due to collaborative efforts and seeking help; strengthened connections with the Latino community

\section{Writing Practices}

MARTIN'S INDIVIDUALISM: Ideas and examples generated from the self rather than the literature; feedback from others not solicited or heeded
RAQUEL'S SOCIAL APPROACH: Ideas and examples generated from the self and literature; feedback from others welcomed

Figure 1

\section{Martin and bootstrapping: the efforts of the individual}

In his constraint agency account, Martin attributed his own personal agency as the driving force in his advancement through college. Martin tended to focus on the actions of the individual, not the institution, as factors contributing to or preventing success. When talking about why other transfer students he knew dropped out or why his peers did not enroll in college, he explained that it is because they were "lazy" and didn't want to work hard (Interview, 11/6/12). Although given the opportunity, Martin did not involve himself in social groups or activities designed to help students through school, such as the academic success center at the university. His reasoning for this is that "men are scared" (Interview, 11/20/12) and don't want to seem weak by seeking out help from others. 
Rather, he adopted a bootstrapping mentality, in which he had to study diligently and succeed by his own will rather than sleeping in class and not studying, which was how he characterized himself before entering university (Interview, 11/06/12). This individualistic ideology of self-help could have partially been inspired by how Martin saw his father progress over the years working at a landfill. Though his father started by picking up trash and received a limited education in Mexico, he is now a manager. When discussing his father's work ethic, Martin described him as working hard and putting in long hours. Likewise, Martin discussed his study habits of reading the entire textbook and staying up until the early morning studying for tests (Interview, 11/06/12). Martin seemed to view his father's work ethic as a model for success and upward mobility.

Martin's emphasis on individual abilities was seen in how he appeared to often reject being a part of the Latino community and a community of Spanish speakers. The culture and language for him did not represent a form of cultural or academic capital that could help him succeed in school. For example, Martin discussed deciding to change the way he dressed and talked in order to fit in at the university and though bilingual, he rarely brought up the fact that he spoke Spanish, and even less so as an advantage. The one time he did was when he discussed the negative experiences he had in a Spanish class taken in college, as he felt it highlighted the fact he didn't speak Spanish “properly” (Interview, 11/20/12).

One specific example of his identity shift was seen in his rejection of being associated with a Latin@ (Latino and Latina) group on campus, MEChA (Movimiento Estudiantil Chican@ de Aztlan, “Chican@ Student Movement of Aztlan”). It is a “student organization that promotes higher education, cultura, and historia" (“About us,” n.d., para. 1) while working toward equality and representation for Latin@s and Chican@s at the university. Martin attended one meeting of MEChA, but never returned, explaining "I joined MEChA for a day but I didn't like it. I didn't like their views" (Interview, 11/6/12). When I asked what 
they were like, he discussed how they had "skewed views" and were "against everything...they blame everything" (Interview, 11/6/12). During this session, Martin and I returned to talking about MEChA and his views on his community. He spoke about being poor and from a single family of five where giving Martin a spare 50 cents cost too much for his father, a fact that contrasted with other Mexican Americans he saw who had more economic capital but did much less with themselves, not wanting to work.

Martin rejected perceived notions of victimization and seemed to dismiss the "constraint" part of constraint agency when it came to himself as a Mexican. He believed that he had much less money than most of the MEChA students and again, comparing his father's work ethic, expressed ideologies of bootstrapping and self-sufficiency:

1 I'm Mexican but I really don't agree with a lot of Mexicans' views ... like they have a weird

2 way of thinking...I think with MEChA there's a lot of self-pity in there...like "oooh my

3 community did this" and I'm like "eh". Like I saw a lot of my friends growing up who had

4 better....My thing was when I was 18, I was like "I'm an adult now...I need to take care of

5 my own actions." But a lot of MEChA or something like that they don't see that - building it

6 themselves...I know it's hard to be like, "ohh, you're like starting at the bottom but you

7 have to move yourself up." It starts with each generation but the generation themselves,

8 they don't want to do anything...so that's why I didn't like MEChA... I think I get it from my

9 dad. My dad's like- I told him I was tired and he was like "you're lazy." 'Cus he goes to work

10 at 2 in the morning and then comes out at like 5 in the afternoon. So he works like a crazy

11 shift...They're like the system puts you down. But I think that your self puts you down.

(Interview, 11/6/12)

In this discussion of MEChA and his family, Martin rejects any effect institutional constraints and capital could have on people's success in life. While maintaining his own Mexican identity, he characterizes Mexicans associated with MEChA as having "self-pity" (Line 2) and not wanting to work or "build" for themselves (Lines 5-6). Martin portrays change as lying in the individual and adopts the idea that people just need to work hard and "pick themselves up by the bootstraps," a commonly accepted American narrative; he also 
refers to the narrative of "starting at the bottom" and moving up (Lines 6-7). He again looks to his father as an example of how to enact agency and progress in life (Lines 9-10).

In addition to hard work, Martin discussed owing his success to not only his efforts but also his individual exceptionalism. Martin told me on more than one occasion that he was "smart" and that he could do what the "smart" kids were doing in school (Interview, 11/01/12). In his eyes, he was gifted and exceptional. This emphasis on individual efforts and school success is linked to Bourdieu's (2012) “ideology of giftedness,” in which a person's "social fate," such as school success, is a result of the person's “individual nature," an ideology that Bourdieu stresses is spurious (Bourdieu, 2012, p. 42):

Neverthelessbelieving that one's innate talents and individual efforts decide one's fate fall under the overarching concept that success is the singular effort of one person rather than a combination of individual and social efforts. Martin emphasized his own success coming from his natural intelligence and his work ethic. I believe he rejected ideas that he wasn't gifted and thus that he could not succeed.

\section{Martin's individualistic approaches to research and writing processes}

This focus on the individual extended into the writing process. During our weekly meetings, Martin mostly discussed his experiences in school and showed little interest in discussing his writing. When we did discuss his work, he often framed the writing process around himself and his ideas. Specifically, Martin would discuss the arguments in the paper and the outside sources in terms of what he did and what his ideas were. To illustrate, while discussing the opening sentence in his final draft, I was trying to clarify what he meant by “remove a student for low income." This question lead to Martin discussing his process of drafting the paper as it related to argumentation and outside sources.

\section{Martin ...And then I just try to argue about the other factors that contribute to}




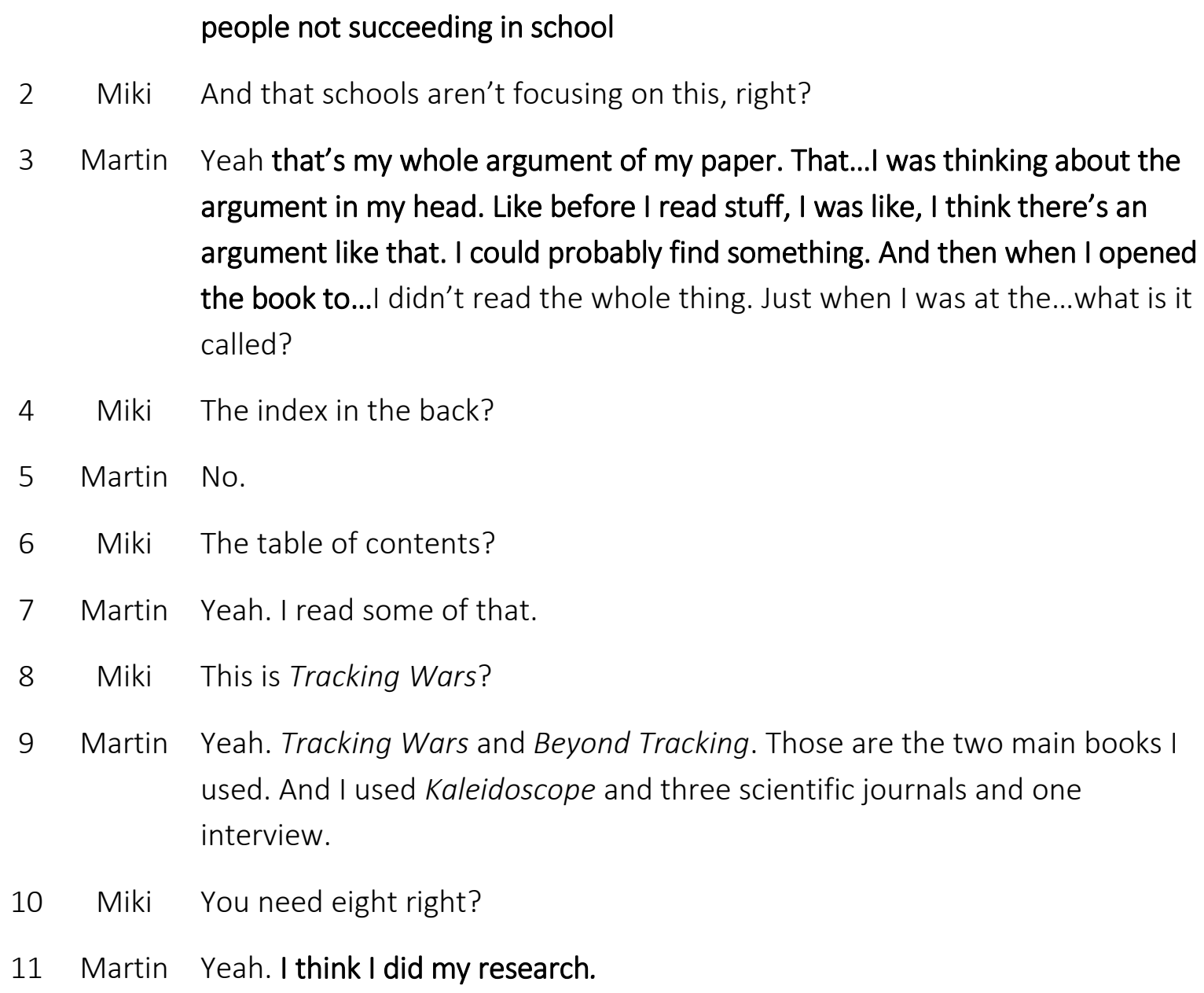

(Interview, 12/7/12)

In this conversation, Martin establishes the arguments of the article as originating from himself, the outside sources merely serving to validate his ideas. In turns 1 and 3 , he focuses on his arguments; in turn 3 he says specifically, "Like before I read stuff, I was like, 'I think there's an argument like that. I could probably find something'”. Rather than an exchange of information or a collaborative process, researching the literature was a means to prove his preexisting points. He appears to be satisfied with the sources he found and the validation they provided for his ideas. His comment "I think I did my research" in turn 11 suggests that his arguments are legitimate because of the outside sources and Martin seemed to acknowledge academic writing practices.

Martin stressed to me not only that the ideas for his research paper originated from him, but also the evidence and language. For example during one of our meetings, I read 
aloud the following sentence Martin wrote in a paragraph that discusses statistics showing Asian immigrants have higher education levels than Latino immigrants and are better at preparing their children to attend college:

This shows that this is not an issue about English deficiency, but social background. Mexican American parents are less likely to encourage their kids to go to college and usually don't see the importance of going to college or are unaware of the requirementneeded to attend college.

(Research paper, draft 1)

I thought that the "don't see the importance of going to college" was an overstatement and controversial for an academic text, so I asked Martin about it. We had been discussing his text and trying to determine which part of the text was his and which belonged to the outside source:

1 Martin This is mine

2 Miki Starting with "this shows that"?

3 Martin Yeah...this is mine

4 Miki Yeah 'cus that's a pretty strong statement. That Mexican American parents don't encourage their kids to go to school? Do you have any evidence to prove that?

5 Martin That- That- those are my words. But then I can use uhh. One of the books we read says that. I think 'why parents don't go to school' or something like that

6 Miki Ok

7 Martin I can support that. I have all these supported facts

8 Miki Do you think most Mexican American parents- Do they want them to? You say they don't encourage them to go to college.

9 Martin Even school. My friends. I mean I'm using personal experience and I've read things but it's a widespread thing

10 Miki Yeah that's fine.

I mention the topic of evidence in academic writing, asking him for "evidence to prove that" in turn 4 , displaying my participation in the discourse that claims need to be supported 
by factual, published data. Martin responded to my question with "those are my words" ( 5), suggesting that the evidence comes from him and his own experience. However, recognizing the need for outside sources to justify this claim, he notes that he had a reading in mind to use. Martin then explained he could support this claim and he had "all these supported facts" (7), emphasizing the legitimacy of his claim against parents like his father, who Martin had described on multiple occasions as not supportive of his education. For example, when Martin told his father that he received an A in class, his father responded, "what's that?" (Interview, 11/1/12). Thus, concerning ideas and evidence, Martin's interaction with others (including myself and outside sources) during his writing process parallel his approaches to schooling, where it is the individual that generates all arguments and examples based on personal experience.

\section{Raquel and social support: social and cultural capital}

The emphasis on individualism in Martin's success story contrasts with Raquel's story of her progress through the university. Raquel identified social contacts and interactions as the driving factors that helped her progress through university, including campus resource centers and her Teaching Assistants (TAs). However, it was not until she struggled through her first year as a freshman, was dismissed from the university, and spent a year at the community college that the importance of social connections and getting help from others became more salient. Like Martin, Raquel's high school experience made her feel less prepared than the other students in her classes at the university. In fact, she expressed regret at not going to a community college first and then transferring (Interview, 4/24/12).

When it came to writing, she felt that in middle and high school she had some good English teachers but did not receive the preparation needed to excel at the university. Based on her college entrance writing exam, Raquel was placed into a developmental writing class in her first year, in which she experienced shame and humiliation at being identified as a poor 
writer (Interview, 4/24/12). She discussed how she received a "C++" on one of her essays, which she saw as a slight to her writing abilities. However, Raquel also discussed not being open to criticism at that time and being too timid to receive help from others (Interview, 4/24/12). In addition, it was only later through email that she discussed her hiatus from the university and how she felt encouraged by her writing instructor to discuss this part of her university experience in her personal statement writing assignment, where she wrote about why she wanted to be an educator.

The process of dismissal and re-enrollment at the university helped Raquel develop important habits for success at the university. She recognized the need to seek social support for academic achievement and discussed going to the writing center and office hours often once re-admitted to the university. In addition, the role of social capital, particularly through the use of mentor, was an important theme in her success story: I discovered that in high school Raquel had an undergraduate student mentor who helped her prepare and apply to college, someone Raquel described as "kind of like the one that pushed me to go to college" (Interview, 4/24/13). Raquel may perceive the social support to have been important to her success, such as the importance of mentors because of their academic capital as knowledgeable members of the academic community. Furthermore, at the university Raquel appeared to be paying this forward by working at a high school mentoring program, where she helped prepare underprivileged Hispanic youth for college. Whereas Martin seemed to downplay his bilingualism, Raquel used her bilingual abilities when translating for one English learner in the program which suggests she recognized her bilingualism as symbolic capital.

However, like Martin, Raquel saw the limitations that her migrant parents with minimal education had when it came to preparing her for higher education because the lack of real and symbolic capital diminished her chances of attending college. Whereas Martin's 
solution was self-reliance, Raquel recognized the use of others through mentorship as a means to help students like her achieve success in college. At the same time, Raquel also very much demonstrated her own agency and will to overcome the constraints and limitations given to her. Raquel's decision to attend community college before returning to the university, as well as her pursuit of internships and research assistant positions in college, demonstrate her own agentive force in ensuring her success. In discussing the success of minorities in high education, Raquel asked for students like her to "step up and ask for help" (Email Correspondence, 5/1/13), meaning that they get the courage to talk to someone about their struggles. Raquel mentioned that she wanted to help others like her if possible, saying:

...If this helps with your research in any way I would be willing to share it with you. I think it is important that minority students step up and ask for help when they need it but many times they fail to do this and suffer the consequences.

(Email Correspondence, 5/1/13)

Her statement stresses the argument that social support drives student achievement, but there is also the message that success and change ultimately lies with the individual exercising his/her agency, in this case by "stepping up." Rather than framing minorities as complete victims, Raquel recognizes the essential role agency plays in student achievement despite the various constraints and lack of capital they might have.

\section{Raquel's collaborative approach to research and writing}

When Raquel discussed her writing with me or wrote writing reflections, she talked about the feedback her instructor or peers gave her and seemed interested in their advice. She was open to ideas proposed during feedback or provided in research articles. Her behavior suggests that she recognized writing as a social practice. I noticed that although Raquel had an argument and wanted to write a persuasive letter, she was influenced by the research she read, unlike Martin, who appeared to seek out studies that validated his own arguments. When discussing her draft, I asked her if she found some information on Hispanic males dropping 
out of school, which could support her argument on the need to have mentoring for Hispanics. Raquel responded by saying she had around six articles on the subject,

"But it was like so much information that it's so hard to kinda pick what I wanted to say."

(Interview, 2/12/2013)

She mentioned the same thing during her written reflection, "I had a difficult time picking specific information out of all of my journal articles.” (Written Reflection). Her responses reveal she appears to be overwhelmed by the amount of information provided in research articles, which is reasonable considering how writers must analyze information from multiple articles before synthesizing them in a paper. But her comments also suggest her writing process involves a dialogic struggle with her sources. Rather than relying on her personal experience alone to write a paper, Raquel seeks out the research of others in order to help her writing, even if it is a difficult process.

Unlike Martin, she asked for my advice on her drafts and saw her draft as just that, something that needed to be improved upon by re-reading articles and browsing through the literature again. The example below demonstrates her social approach to the writing process and familiarity with symbolic capital. During our conversation about her draft, I mistakenly interpret Raquel's discussion of cultural capital. I thought she was saying that Latinos lack the cultural capital to succeed in education, but in fact she was saying the opposite. She tries to clarify her point to me by discussing a reading she referenced:

1 Raquel OK 'cus in the reading, maybe I like, I understood it wrong.

2 Miki Mmhmm

3 Raquel But in the reading it talked about how like how the schools should focus on, you know, the Latinos having this cultural capital and having, you know, this extra thing that they bring to the table, basically.

4 Miki No, yeah that's- that's the- that's the other side of the argument, right?

5 Raquel Mmhmm

6 Miki That we shouldn't have to, uh, conform to one type of culture to be 


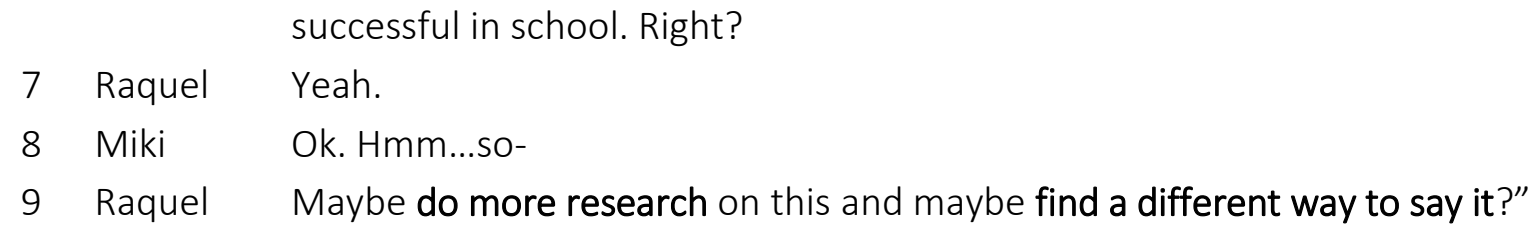

First, Raquel opens up the idea that she misinterpreted a reading in turn 1 , demonstrating that she does not know everything and that reading involves interpretation. She then explains her interpretation of the argument in turn 3 and how Latinos have cultural capital that should be embraced in schools. Raquel discusses the possibility of doing more research and then to "find a different way to say it" (turn 9). This suggests again that she seeks out help from others via the literature in order to create a paper that can be understood by the reader. Because I, as a reader, misinterpreted her, Raquel suggests reformulating the discussion; because I was a writing tutor, she could have wanted to avoid challenging me or thought I had more capital on the issue Rather than endeavoring alone, Raquel engaged me as a writing tutor, her peers and outside sources as resources to help her succeed in her writing. At the same time, Raquel demonstrates an awareness of symbolic capital and believes that she as a Latina has cultural capital.

\section{Discussion}

Writing is an inevitably complex, multi-faceted and unique experience and this study's purpose was to better understand it by analyzing the interaction of the lived experiences, constraint agency, and identity of two individuals, Martin and Raquel. The two research questions sought to understand student success strategies and their influence on writing. First, Martin described his educational success as coming from his individual efforts and talents, whereas Raquel attributed social support as the factor in her success. Second, their approaches to school appeared to influence their writing process: Martin tended to resist feedback and sources served as a backdrop for his claims, whereas Raquel was receptive to feedback and 
the ideas in outside sources. Martin tended to frame the process as an individualistic endeavor. Raquel framed the process as a social experience where students seek out others who have the skills to help. However, this is not a simple situation where one approach is better than the other. Both students made it through their $4^{\text {th }}$ year in their undergraduate career. Both were strong characters determined to succeed. Their frameworks for approaching writing and schooling demonstrate Bourdieu's (1977) theories on education and academic achievement. Martin and Raquel's lack of real and symbolic capital (Bourdieu, 1991) hindered their chances for making it to college. Nevertheless, they both made it, which reflects just how much agency they had, despite constraints. It seems that individual agency should not be overlooked when it comes to academic achievement (Kanno \& Harklau, 2012). A variety of paths exist for the same ending, but in the case of Raquel and Martin, it is important to consider their educational outcomes. Martin's success story and actions during our writing interactions suggest that he believed in individual effort and intelligence for success. However, it appears that his refusal to seek out others with the academic, linguistic, and social capital to succeed in college hindered his chances of success. Lacking a social network, Martin missed out on what Reyes called "key interactions" with adults in mentorlike roles that could have helped him with his classes and writing (Reyes, 2009). It seems that for at least some immigrant Latino males in high school, receiving social support and cultural capital helped with student academic achievement (Hopkins et al., 2013). The subject of individualism and ethnic identity in education remains an interesting topic to explore.

Just as she helped Latino high school students, Raquel's tutoring aide at the university influenced Raquel's achievement. Research suggests mentors may help minority student retention at the university (Reyes, 2011). Her experience reflects what Mills and Gales (2007) argue about the possibility to exert agency, despite constraints from limited types of capital while quoting Bourdieu et al. (1999): "what the social world has done, it can, armed with this 
knowledge, undo" (p. 629 as quoted in Mills and Gales, 2007 p. 444). Equipped with the knowledge about types of capital and school success, Raquel was able to change her outcomes at the university. In addition, Raquel was brave enough to ask for help once back at the university, an affective aspect worth exploring. It is one thing for students to recognize their limited symbolic capital, but it is another thing for them to get the courage to seek help from others and identify themselves as students in need, which reveals vulnerability. Martin too seemed aware of this when he told me that men were "scared" to seek out help. Perhaps what Martin missed was that courage is not the lack of fear; it is carrying out an action despite one's fears. When Raquel asked students to "step up," perhaps she was asking them to exercise their agency despite being "scared." Indeed, gender appears to be an important factor, and the lack of exploration of the ways it intersects with identity, symbolic capital, and academic achievement remains a limitation of the study However, future research is merited on this subject.

\section{Conclusion}

The study focused on understanding the success strategies and writing processes of two individuals who came from backgrounds with limited economic and symbolic capital needed to not only enter but also continue through higher education. By describing Raquel's and Martin's experiences in school and their writing processes, the study strove to give voice to two individuals whose stories, although pertinent and interesting, often go unheard. As these were two case studies, findings and arguments need to be considered and approached from the situation-specific research context. What readers could do is consider similarities other case studies might have, such as the population or type of writing being done, and compare them in order to understand multiple perspectives; readers can "explore the meanings that a similar experience has" (Menard-Warwick et al., 2013, pp. 969-970). Although this study looked at two Mexican American students on the West Coast, results 
could be compared against similar writing contexts of students on the East Coast of Puerto Rican heritage, for example.

In conclusion, learning about Raquel's and Martin's educational histories and writing practices suggest success strategies that students may employ to graduate from college, after making it there (Harklau, McClanahan, \& Mendez, 2012). Because students bring with them a variety of lived experiences, it may prove useful for writing instructors to discuss the value of support systems and the socially dependent nature of writing. Also, future research may want to address other ways in which writing practices intersect with student approaches to academic achievement in order to equip students with practices that will help them graduate from university. Writing centers and programs may want to consider how students' writing practices encompass more than just "composition," because past experiences and identities influence how students approach writing at the university.

\section{References}

"About us," (n.d.) Movimiento estudiantil chican@ de aztlan: Official national website. Retrieved from http://www.nationalmecha.org/about.html

Bourdieu, P. (1977). Cultural reproduction and social reproduction. In J. Karabel \& A. H. Halsey (Eds.), Power and ideology in education (pp. 487-511). Oxford: Oxford University Press.

Bourdieu, P. (1991). Language and symbolic power. Cambridge, United Kingdom: Polity Press.

Bourdieu, P. (2012). The school as a conservative force: scholastic and cultural inequalities. In J. Eggleston (Ed.), Contemporary research in the sociology of education (pp. 3246). New York: Routledge.

Brammer, C. (2002). Linguistic cultural capital and basic writers. Journal of Basic Writing, 21(1), 16-36. 
Collins, J. (1999). The culture wars and shifts in linguistic capital: For combining political economy and cultural analysis, International Journal of Qualitative Studies in Education,(12)3, 269-286, DOI: 10.1080/095183999236132

Comfort, J. R. (2000). Becoming a writerly self: College writers engaging black feminist essays. College Composition and Communication. 51(4), 540-549.Duff, P. (2008). Case study research in applied linguistics. New York: Lawrence Erlbaum Associates.

Freeling, N. (2015). UC leads nation's top universities in serving Latino students. From UC Newsroom retrieved from http://www.universityofcalifornia.edu/news/uc-leadsnations-top-universities-serving-latino-students

Hall, S. (1996). Introduction: Who needs 'identity'? In S. Hall \& P. du Gay (Eds.), Questions of cultural identity (pp. 1-17). London: Sage.

Harklau, L. \& McClanahan, S. (2012). How Paola got to college: One Latina's unlikely college success story. In Y. Kanno \& L. Harklau (Eds.), Language minority students go to college: Preparation, access, and persistence (pp. 74-90). New York: Routledge.

Holland, D., Lachicotte Jr., W., Skinner, D., \& Cain, C. (1998). Identity and agency in cultral worlds. Cambridge, Massachusetts: Harvard University Press.

Hopkins, M., Martinez-Wenzl, M., Aldana, U.S., \& Gandara, P. (2013). Cultivating capital: Latino newcomer young men in a U.S. urban high school. Anthropology \& Education Quarterly, 44(3), 286-303

Ivanic, R. (1998). Writing and identity: The discoursal construction of identity in academic writing. Philadelphia: John Benjamins Publishing.

Ivanic, R., \& Camps, D. (2001). I am how I sound: Voice as self-representation in L2 writing. Journal of Second Language Writing, 10(1), 3-33. 
Kanno, Y. \& Cromley, J. (2013). English language learners' access to and attainment in postsecondary education. TESOL Quarterly, 47(1), 89-121.

Kanno, Y. \& Harklau, L. (2012). Language minority students go to college: Preparation, access, and persistence.New York: Routledge.

Kanno, Y. \& Varghese, M. (2010). Immigrant and refugee ESL students' challenges to accessing four-year college education: From language policy to educational policy. Journal of Language, Identity, and Education, 9, 310-328. doi:

$10.1080 / 15348458.2010 .517693$.

Lee, S. H. (2010). Attribution in high- and low-graded persuasive essays by tertiary students. Functions of Language, 17(2), 181-206.

Liu, P. H. E., \& Tannacito, D. J. (2013). Resistance by L2 writers: The role of racial and language ideology in imagined community and identity investment. Journal of Second Language Writing, 22(4), 355-373. doi: 10.1016/j.jslw.2013.05.001

Menard-Warwick, J., Heredia-Herrera, A., \& Palmer, D. S. (2013). Local and global identities in an EFL internet chat exchange. The Modern Language Journal, 97(4), 965-980. doi: 10.1111/j.1540-4781.2013.12048.x

Mills, C., \& Gale, T. (2007). Researching social inequalities in education: Towards a Bourdieuian methodology. International Journal of Qualitative Studies in Education, 20(4), 433-447. doi: 10.1080/09518390601176523

Norton, B. (1997). Language, identity, and the ownership of English. TESOL Quarterly, $31(3), 409-429$.

Ortmeier-Hooper, C. (2008). "English may be my second language, but I'm not 'ESL'. College Composition and Communication, 59(3) 389-419.

Ramanathan, V., \& Atkinson, D. (1999). Individualism, academic writing, and ESL writers. Journal of Second Language Writing, 8(1), 45-75. 
Reyes, M.E. (2011). A sophmore-to-junior mentoring program that works: The SAM program at the University of Texas Pan American. J. College Student Retention, 13(3), 373382.

Santiago, D.A., \& Calderon Galdeano, E. (2014). Latino college completion: United States.

Retrieved from Excelencia in

Education,http://www.edexcelencia.org/research/college-completion/united-states.

Strauss, A. (1987). Qualitative analysis for social scientists. Cambridge: Cambridge University Press.

U.S. Department of Education, National Center for Education Statistics. (2015). The condition of education 2015 (NCES 2015-144), status dropout rates. Retrieved from https://nces.ed.gov/fastfacts/display.asp?id=16

Varghese, M. (2012). A linguistic minority student's discursive framing of agency and structure. In Y. Kanno \& L. Harklau (Eds.), Linguistic minority immigrants go to college: Preparation, access, and persistence. New York: Routledge.

Walpole, M. (2003). Socioeconomic Status and College: How SES Affects College Experiences and Outcomes. The Review of Higher Education, 27(1), 45-73.

Watson-Gegeo, K. (1992). Thick explanation in the ethnographic study of child socialization: A longitudinal study of the problem of schooling for Kwara'ae (Solomon Islands) Children. New Directions for Child Development, 58, 51-66.

Welch, N. (1996). Revising a writer's identity: Reading and "re-Modeling" in a composition class. College Composition and Communication, 47(1), 41-61. 